\title{
UCLA
}

InterActions: UCLA Journal of Education and Information Studies

Title

The 500 Windows Campaign: A Case Study of a Youth Movement for Educational Resources in South Africa

Permalink

https://escholarship.org/uc/item/7r8387bx

Journal

InterActions: UCLA Journal of Education and Information Studies, 7(2)

ISSN

$1548-3320$

Author

Angara, Harini

Publication Date

2011-05-31

DOI

10.5070/D472000696

Peer reviewed 


\section{The 500 Windows Campaign: A Case Study of a Youth Movement for Educational Resources in South Africa}

Fifteen years after the end of institutionalized racial segregation in South Africa, the country has made great strides towards equality. However, it still grapples with enormous disparities in wealth and access to quality education. Economist Andrew Rechovsky (2006) notes the stark differences between schools in different areas of the country:

While some schools have highly qualified teachers and a full range of education facilities, such as science laboratories and well-stocked libraries, other schools must rely on many unqualified teachers and lack even basic facilities and supplies such as working toilets and a sufficient number of classrooms for their students. (p. 21)

These educational inequities are pronounced in Khayelitsha, a township on the outskirts of Cape Town, one of South Africa's capital cities. Schools in Khayelitsha struggle with a range of difficulties, including teacher absenteeism, a shortage of textbooks, and broken toilets (Shushwana \& Mzandisi, 2008). One of the most visible issues is the large number of broken windows at the schools. In mid-2008, education activists and local high school learners ${ }^{1}$ created an organization, Equal Education (EE), to campaign for equitable educational conditions in Khayelitsha. The campaign's initial goal was to convince local officials to fix the 500 broken windows ${ }^{2}$ at Luhlaza School. Learners from across all Khayelitsha schools participated in solidarity. EE members planned their approach and kept one another informed in weekly meetings. Despite opposition from several local officials, the youth members held meetings with the provincial education department, created petitions, wrote articles, gave talks on local press and radio, and organized a rally in downtown Cape Town. Ultimately, the Equalisers succeeded not only in having the windows fixed, but in obtaining more than what they had expected - a promise from the government to invest $\mathrm{R} 671,000^{3}$ in Luhlaza School, well above the R7,000 that EE had requested for the window repair.

EE was successful in achieving the goals of its 500 Windows Campaign because it made excellent use of several grassroots strategies, namely employing collective decision-making to establish goals, gaining broader support from government officials as well as other students and community members, and utilizing the diverse skills of its members. Unlike many youth movements, EE began with the support of established activists, such as Zackie Achmat. This support, coupled with EE's organized and collaborative approach, contributed to the campaign's success. Additionally, unlike many grassroots movements that

disband after achieving a short-term goal, EE evaluated the strengths and 
weaknesses of its first campaign in order to plan for subsequent campaigns. EE's first campaign is worth examining not only because it set a positive precedent and provided examples of effective strategy for subsequent work, but also because the strategies EE employed can serve as a useful model for other grassroots movements. In particular, the EE organization provides a strong example of adults and youth working together on a social campaign. The adult leaders of EE organize and provide resources to the youth, while the youth lead the major mobilization efforts. This vital adult-youth relationship is an example of an "adult-initiated [effort] with shared decisions with the youth campaign" (Hart, 1992, 1997).

While a great deal of scholarship exists about anti-apartheid activism, there has been little analysis of social activism in the post-apartheid era, particularly among youth. The purpose of this case analysis is to examine one shining example of post-apartheid youth activism. Additionally, a detailed study of EE provides valuable historical analysis. I begin with a brief discussion of the factors that tend to incite youth movements, reasons why young people become involved, commonalities across youth social movements, and why these movements can effect social change. I then describe the context of educational inequity in South Africa, beginning with an account of education under apartheid, the system of racial segregation practiced by the South African government under the white Afrikaner National Party from 1948 to 1994, as well as youth activism at that time, within the larger context of the struggle against apartheid. While these discussions will not cover the full breadth of South African history regarding apartheid, the struggle against it, and its eventual dismantling, I hope it will provide a basic primer about the precursors to EE. I follow these descriptions with a brief explanation of the current structure of education governance and state of schools in order to describe the contemporary backdrop behind EE's work. Subsequently, I provide a detailed account of EE's creation and the 500 Windows Campaign, as well as an analysis of the group's approach using grassroots social action concepts (Willie, Ridini, \& Willard, 2008). Finally, I provide a glimpse into EE's lessons learned and its endeavors after the 500 Windows Campaign, including the implications of its work for other grassroots social movements.

\section{Youth Social Action}

Existing literature on youth social action comprises ethnographic studies of youth participation in community development, particularly case studies of single projects, and a smaller number of meta-analyses and large quantitative studies (Lekiesa, Baker, \& Baldini, 2009). Most studies concern youth participation through organizations led by adults, of which youth are members (e.g. Barnett \& Brennan, 2006; Lekiesa et al., 2009). Additionally, most studies 
discuss youth social action through the analytical framework of youth development and civic education (e.g., Barnett \& Brennan, 2006; Kirshner, 2009). Barnett and Brennan (2006) discuss civic engagement on the part of youth as a process of youth finding their own values by participating in a shared social effort and building engagement processes that prepare them to be engaged adults. They describe three developmental stages of youth leadership: awareness, interaction, and mastery, which refer to a learning curve with increasing levels of social responsibility for youth.

Alternatively, Delgado and Staples (2008) examine youth social action through the analytical framework of community organizing theory. Rather than emphasizing the psycho-social development of youth, they focus on the youth organizations as entities in and of themselves. They describe nine organizing principles: inclusive membership; social and economic justice; support for change; training, mentoring, and leadership opportunities; adult involvement; long-term agenda; consciousness-raising; fun and learning; and shared vision. Additionally, they find that youth movements share ten framework elements: goals and objectives; structure; staffing; leadership; participation; communications; allies; finances; strategy and tactics; and target systems.

Hosang (2006) draws closer attention to the ways in which political and social discourse can either support justice or distort it, and he describes the ways in which youth activists have attempted to redefine the discourse around youth engagement in education. He criticizes the prevailing deficit models of viewing youth as troubled and unable or unwilling to learn, in which "students are understood as the primary authors of the schools' failure" (p. 9). Hosang argues that this bias influences policy decisions, in which spending on the expansion of state prisons is deemed a necessary and inevitable expenditure, but spending on the improvement of schools is seen as "throwing money at the problem"” (p. 8). This rhetoric determines how youth will be treated by adults before youth even have a chance to speak for themselves. In a case study of a community group, InnerCity Struggle (ICS), Hosang examines the ways in which youth activists do speak and influence the community's understanding of their local high school. At Roosevelt High School in East Los Angeles, 68 percent of students do not graduate. These students are commonly described in educational discourse as "dropouts." This term suggests that dropping out is entirely a student's choice, that the student was provided with all of the resources necessary to succeed but lacked the intelligence or drive to make use of it. In reality, Roosevelt is a poorly funded high school with 5,100 students, one of the largest in the country, where as many as 65 students are packed into classes meant for 30 students and there is only one guidance counselor for the entire student body. Using a framework coined by an ally organization, ICS redefines the "dropouts" as "disappeared students," thus challenging the established view and replacing it with one that 
draws attention to educational inequities. During weekly lunchtime meetings, ICS student organizers discuss these inequities and have put their discussions into practice with a successful campaign to make rigorous college preparation coursework available to all students, not just those in the honors track. The reclaiming of the discourse around educational issues that Hosang documents speaks to the fundamental shifts that must occur in order to truly remedy educational inequities. The discourse is not just terminology, but a powerful framework that defines how these issues are approached. Thus, youth-defined discourses provide another alternative framework for examining youth social action.

Youth movements in the area of education are particularly effective because school life occupies much of young peoples' time and energy. Moreover, in school settings, youth are already organized and interact in groups-in classes and extracurricular activities, for example. Two major ways in which youth begin to take part in social action in education are through preexisting outlets or as a response to conditions or actions deemed unfair by youth. As Lekiesa et al. (2009) posit, youth tend to become involved in community development activities through existing organizations in which they participate. Preexisting outlets for youth social action can take various forms, but typically exist at the school itself and are often initiated and maintained by adults, with various levels of leadership from youth. Lekiesa et al. (2009) note that the adult-youth relationship is significant in a youth social movement because adults provide mentorship, skillbuilding, and encouragement. At the same time, in an ideal scenario, youth are involved in the decision-making process. Youth involvement through preexisting outlets is often particularly dependent upon adult mentorship. Examples of preexisting outlets include classes on human rights and social justice, extracurricular activities focused on civil rights, such as Amnesty International student groups, and community programs that partner with schools, such as Peace First.

Another pattern of youth involvement in social action is in response to conditions or actions on the part of decision-makers that are deemed unfair by youth. As Kirshner (2009) mentions, one view of civic identity formation is that people engage in social action, particularly community organizing, in order to address social problems that directly affect their lives. Kirshner characterizes this type of social action as both "generative, because it works to contribute to a public good and self-interested, because it seeks to improve one's lot" (p. 415). In educational contexts, this type of social action is particularly powerful because it pertains to conditions that adult decision-makers have not been able to, or choose not to, make equitable. Kirshner notes that "the ability to organize others and advocate for shared interests is especially important in social contexts where youth lack resources that more privileged youth take for granted, such as well- 
maintained school facilities or subsidized transportation to school" (p. 415). Because these conditions directly affect youths' lives and because they are conditions that adults have not adequately addressed, youth are more likely to take action independent of adult guidance.

Youth social action through preexisting outlets and youth social action that is initiated by youth themselves differ in terms of the level of support from adults and the ways in which youth learn about the issues. However, they do share some common elements. In both situations, members of the group identify their goals and desired outcomes and develop a focused campaign that addresses one aspect of the issue, at least in part as a symbol of the issue itself. Additionally, they develop a plan to implement the campaign by determining discrete steps. Among these youth movements, Equal Education is unique because it is neither fully youth-initiated, nor is it a preexisting outlet that is part of an umbrella adult initiative. For example, it is a learner's photo of broken windows that launches the campaign, and youth activists are the main actors in generating publicity and recruiting more members for the group. At the same time, adults guide many of the meetings with high-level education officials. Overall, EE's 500 Windows Campaign exhibits a combination of elements from both styles of youth engagement.

\section{Case Analysis}

The purpose of this case analysis is to understand the factors that led to the success of Equal Education's 500 Windows Campaign. In order to develop a multifaceted view of EE's work, I spoke with Doron Isaacs, one of EE's leaders, and reviewed the EE website and documents, including annual reports and news articles about the organization's work. As a non-governmental organization, EE releases an annual report to the public, which provides information on the organization's financial records, as well as programmatic information. EE's 2008 annual report describes the actions EE members took during the 500 Windows Campaign in detail. As such, the annual report is a major resource in the description of the case. As a framework to guide my analysis, I use sociologist Charles Willie's theories of social action, as outlined in his books Grassroots Social Action (with Steven Ridini and David Willard, 2009) and Theories of Human Social Action (1994). Willie's theories relate to the ways in which successful social movements develop. He organizes the structure of grassroots campaigns into four stages: initiation, legitimation, implementation, and

evaluation. Willie is also concerned with collective decision-making and the partnerships that form between diverse individuals with common interests.

Willie's (1994) theories are based on the idea of contributive and distributive justice, a belief that governments and their citizens have a mutual 
responsibility in assisting one another. I refer to this concept as the ethos of the campaign. For youth, this can refer more specifically to schools and other adultrun social structures and their obligations to serve citizens. While citizens have responsibilities to uphold the law, the government has a reciprocal responsibility to ensure that its citizens have equal and fair treatment under the law. Using additional ideas from Willie about diversity, vertical linkages (partnerships with influential decision-makers), and critical mass (a large enough group of supporters necessary to making an impact), I examine the leadership and membership of EE, the chronological stages of the campaign, the composition of the group, and the members' interactions with one another, with their community, and with the opposition.

\section{Historical and Structural Context of the Case}

Although education in South Africa today is beginning to move past its legacy of apartheid, the disparities established during that era still exist. Under apartheid, a system of strict racial segregation that ended only fifteen years ago, educational differences between white South Africans and black South Africans were stark. The government established a separate "Bantu" education system, which purposely sought to provide black students with only the level of education necessary to serve as laborers (Dugger, 2009). Hendrik Verwoerd, the prime minister who was the chief planner of apartheid, defended the education system for black South Africans, declaring that "Natives must be taught from an early age that equality with Europeans is not for them... What is the use of teaching the Bantu child mathematics when it cannot use it in practice?" (South African History Online, 2000).

In a study of education finance under apartheid, economists Johannes Fedderke, Rapael de Kadt, and John Luiz (2000) report that spending per pupil was almost seven times higher for white students compared to black students. The disparity in per-pupil spending manifested itself in vastly different levels of teacher salaries and teacher-student ratios, school facilities, and supplies. Fedderke and Luiz (2002) found that real spending increases in South Africa result in increases on the pass rate on matriculation exams. Thus, because of the differences in educational spending for black South African students as compared to their white peers, wide racial disparities in educational attainment existed. Among South Africans who were age 30 in 1993, whites had completed above 12 years of education on average, while blacks had completed only 8 years on average (Rechovsky, 2006). The low level of educational attainment translated into high rates of illiteracy; 66 percent of youth and adults between the ages of 16 and 34 were functionally illiterate in 1990, according to a South Africa Department of Education (2000) report. These educational differences are 
evidence of the degree to which apartheid had systematized inequality. Although apartheid no longer exists, its legacy still impacts the current state of education in the country.

\section{Youth Social Action against Apartheid in South Africa}

The youth movements against apartheid set a precedent for youth civic engagement in South Africa that continues to this day through organizations like Equal Education. Youth movements against apartheid were catalyzed by the passage of the Afrikaans Medium Decree of 1974, which mandated a 50 percent50 percent mix of instruction in Afrikaans and English in black schools. Prior to the passage of this law, the schools had used a mix of English and native languages in instruction. The new law was unpopular with students as well as many teachers because, in the words of Desmond Tutu, Afrikaans was considered to be "the language of the oppressor" (South African History Online, 2000). After appeals to the government went unheeded, learners in the township of Soweto decided to stage a nonviolent protest through their student organization, the Soweto Students Representative Council.

On June 16, 1976, thousands of learners from Soweto schools marched to Orlando Stadium, where they had planned to hold a rally (Goodman \& Goodman, 2008). Their march was blocked by police who shot tear gas at the unarmed children. In response, some children began throwing rocks at the police. The police retaliated by opening fire on the learners. More than five hundred children were killed (Goodman \& Goodman, 2008). Among those children was 12-yearold Hector Pieterson. Sam Nzima, photographer for a local black newspaper, The World, took a picture of the scene: Hector being carried by his grieving classmate Mbuyisa Makhubo, flanked by Hector's sister Antoinette. The photo was published in newspapers around the world and became emblematic of both the suffering caused by apartheid and youth action to change this system.

The event, which came to be known as the Soweto Uprising, was a watershed in anti-apartheid youth activism, both within and outside South Africa. In South Africa, youth leaders became more active through the National Union of South African Students (NUSAS), the South African Students' Organisation, the Congress of South African Students, and other liberation groups. As these groups were composed of students, they were particularly concerned about equality in education. NUSAS was originally founded as a white students' organization, but in 1945 admitted its first black university. In the fifties, NUSAS officially opposed segregation in tertiary education. Later, it expanded beyond education issues to support the anti-apartheid movement by calling for American companies' divestment from South Africa and campaigning to free political prisoners. NUSAS was one of the few predominantly white organizations that actively fought apartheid. 
At the same time, many black members felt that NUSAS was not strong enough in its stance and that despite its calls for reform, it still engaged in discriminatory practices, such as housing black members in quarters further away from the conference center than white students during a 1967 conference. Under the leadership of Steve Biko, the dissidents formed the South African Students' Organisation (SASO). SASO was guided by Black Consciousness principles and sought to establish a solid black identity among its members. This stance made the organization controversial, but Biko and the SASO leadership also made partnerships with other anti-apartheid movements. Among other priorities, such as quality healthcare, SASO engaged in several education initiatives, such as a literacy campaign and college campus-based boycotts to protest segregation at the tertiary level. Moreover, SASO was one of the first organizations to reject the Bantu education system altogether-that is, not only the segregation of black and white students, but also the curriculum itself, which reiterated white supremacy. SASO passed a declaration of student rights, which included the thencontroversial right to dissent with professors (South African History Online, 2000). Additionally, SASO created an education commission to study ways that education could be made more relevant to black students. SASO also passed an Education Manifesto, which rejected the idea that universities were neutral purveyors of knowledge. SASO led political education classes for younger students in black schools.

The Congress of South African Students (COSAS) started in 1979 and launched a nationwide boycott of schools as a protest of unequal school facilities and resources, poorly trained teachers, and corporal punishment. In response, the government imprisoned the organization's leaders and many members. However, by 1983, COSAS had started its "Liberation before Education" campaign, continuing the boycott with even greater intensity. They also helped promote the idea of "people's education," that is, that the South African curriculum include non-Western peoples, particularly the history, languages, and culture of black South Africans (O'Malley, 2005).

Equal Education owes much of its philosophy to the precedent set by these apartheid-era student groups, as they first established education as a rallying issue among South African young people. For example, EE borrows the idea that youth have the right to dissent with adults and that students should voice their educational needs and demand that those with decision-making power meet those needs. Like earlier organizations, EE wants youth to take part in the educational decision-making itself, rather than be passive followers of government decrees. The enthusiasm around EE campaigns, in many ways, carries over from the collective memory of youth campaigns in the apartheid era. During EE meetings, students often read the writing of anti-apartheid activists and relate their own work to this struggle. Some of these predecessors' methods, such as public 
protests and rallies, influence EE's own campaigns. Although educational inequities persist, the context in which EE operates is significantly different from that of the apartheid-era organizations. EE exists in a much more integrated society, under a constitution that promises equality. Thus, EE's methods of protest tend toward the politically moderate, emphasizing letters, rallies, and meetings with officials more often than boycotts. Moreover, EE's leadership and membership is diverse and integrated; the group's leadership is of varying social class, ethnicity, and hometown. This diversity is significant not only because it speaks to the progress that has been made in developing a more integrated society, but also because it helps to emphasize education as a focus issue among various constituencies.

\section{State and Structure of Education in the New South Africa}

After Nelson Mandela was inaugurated as South Africa's first democratically-elected president, a new constitution was written and adopted in 1996. It provided for a new system of public education in South Africa, with its bill of rights guaranteeing all South Africans the right "to basic education, including adult basic education; and to further education, which the state, through reasonable measures, must make progressively available and accessible" (Constitution of the Republic of South Africa, 1996. chap. 2, sec. 29). As outlined in the Constitution, responsibility for basic education is shared between the national and provincial governments, through "concurrent legislative competence" (Constitution of the Republic of South Africa, 1996. chap. 2, sec. 29). The democratically elected provincial governments have the responsibility of providing education to their respective constituents. Through a "uniquely South African system of federalism" (Rechovsky, 2006, p. 26), the national government provides most of the provincial governments' revenues through grants. Provincial governments have a degree of autonomy in education policy, but must make decisions in keeping with a set of national norms and standards (Rechovsky, 2006).

Each province's department of education is directed by a Minister of Education and a Superintendent-General, as well as the Member of the Executive Council (MEC), a provincial Cabinet member who is appointed by the premier of the province (Western Cape Education Department [WCED], 2010). They are accountable individually and collectively to the provincial legislature (SouthAfrica.info, 2010). Each school district is overseen by a district office, which is responsible for "providing support and advice to schools with regard to management and governance; educator and learner support; and curriculum matters and administration (including finance)" (WCED, 2010). The districts are further broken down into circuits, overseen by Circuit Managers and their teams. Circuit Teams are composed of curriculum advisors, psychologists, social 
workers, administrative development advisors, and other staff responsible for the state of education in the circuit and schools' primary liaisons to the provincial government (WCED, 2010).

In terms of financing education within the province, provincial governments are limited in the amount of revenue they can raise from taxes, but they are permitted to levy school fees from students, with low-income students granted fee exemptions. Major improvements have been made in the relatively short span of time during which democratic governance has been established. For example, public school spending per white student is now 1.5 times that of spending for black students (Rechovsky, 2006). However, because many schools in South Africa are still de facto segregated by race and class, schools in wealthier areas raise significantly more revenue through school fees than schools in poorer areas raise, which allows wealthier schools to spend more money per student. In the Western Cape, the province where Khayelitsha is located, nearly all students attending formerly black schools are black and nearly all white students attend formerly white schools, although the schools are now legally integrated (Rechovsky, 2006). Average school fees in formerly black secondary schools were R105, while those in formerly white schools were R2,701 (Fiske \& Ladd, 2004). The level of school fees is determined by parents at individual schools. Thus, although the education finance system encourages middle-class families to stay in the public school system, it has created a system whereby a small number of schools in high-income districts are able to provide a much higher quality education than less-resourced schools in many other parts of the country (Rechovsky, 2006). The resource difference translates into tremendous differences in educational achievement: only 2 out of 1,000 sixth graders in formerly black schools in the Western Cape passed a mathematics test at grade level in 2005, compared with almost 2 out of 3 children in formerly white schools (Dugger, 2009).

\section{Equal Education's 500 Windows Campaign in Khayelitsha}

\section{About Khayelitsha}

Khayelitsha, a township located in the Cape Town metropolitan area in the Western Cape province, was first established in 1983 by the apartheid government in order to manage the migration of rural black South Africans to the city (Integrated Regional Information Networks [IRIN], 2009). In keeping with the government's practice of isolating black South Africans from contact with white communities, apartheid planners set the township far from the city's commercial center and away from reliable transportation. Originally intended to house 220,000 people, the township is now home to more than 10 times that number (IRIN, 2009). In addition to government public housing in the township, informal 
settlements, such as Site B and Site C, have since grown. Over 50 percent of Khayelitsha's population is unemployed (IRIN, 2009).

Khayelitsha's schools struggle with obtaining many basic educational necessities. At KwaMfundo School, a secondary school profiled in a September 2009 New York Times article, teacher absenteeism is a major problem, and students' pass rates on the matriculation exams, which determine secondary school graduation and college entry, dropped to just 44 percent (Dugger, 2009). Students at the school made a complaint to the principal about an accounting teacher who was chronically absent and asked for a new teacher. After seeing no action taken, the students directed their anger at their teachers with violence (Dugger, 2009). In the midst of this discontent, Equal Education, a community movement dedicated to obtaining resources for Khayelitsha's schools through nonviolent means, emerged in 2008.

\section{The Founding of Equal Education}

The Equal Education organization was the brainchild of Zackie Achmat, a well-known activist who was 14 years old when he participated in the 1976 Soweto uprising and has since been a tireless advocate for AIDS treatment and LGBT rights (Karon, 2001). Although Achmat is the inspiration behind EE and provides advice as a board member, he has recruited a new, younger generation of activists to run the organization. Doron Isaacs and Yoliswa Dwane, recent law school graduates of the University of Cape Town (UCT), are two of the organization's leaders. Isaacs had previously been involved in Achmat's Treatment Action Campaign and with Habonim, a Jewish youth movement, work that cemented his interest in politics and gave him valuable experience in organizing youth campaigns and managing large-scale projects (D. Isaacs, personal communication, December 5, 2009). Dwane, a classmate of Isaacs, grew up in a low-income community of the Dimbaza township in the Eastern Cape. She went on to earn a degree in Media, Film, and Visual studies at UCT, followed by a law degree (Equal Education [EE], 2008). In addition to Isaacs and Dwane, several staff members work closely with learners on the youth campaigns: Joey Hasson, who previously worked for the Treatment Action Campaign and was a member of Habonim; Lwandiso Stofile, who graduated from Harry Gwala High School in Khayelitsha before working on AIDS issues; and Nokubonga Yawa, who works with learners in grades eight and nine (EE, 2008). The organization has a number of other dedicated staff members, and five of the twelve staff members attended schools in Khayelitsha, including KwaMfundo School. Most importantly, however, EE has youth group leaders and several hundred youth group members from schools across Khayelitsha. It was their spirit and desire for equal educational opportunities that was the driving force behind the 500 Windows Campaign. 
While there are other youth movements working for equitable education in South Africa, EE is unique as a grassroots movement that links learners, parents, teachers, and other members of the local community with decision-makers in government in a productive way. Unlike COSAS, which was originally founded as a youth-led anti-apartheid movement in South Africa, EE does not engage in active disruption of educational time and resources. For example, when the local government decided to close Lagunya Finishing School, COSAS members entered a neighboring school, Thembelihle High School, and tore up students' exam papers as a form of protest. In a press release, EE condemned the act, stating that while EE shares the same ideals as COSAS for an equitable education system, "such anger will lead only to low expectations of youth leadership if a youth organisation destroys school infrastructure and the future of other young people of this country" (Dwane, 2009). The press release further described EE's wish to involve a broad range of constituents in efforts to improve schools and its emphasis on augmenting existing resources, rather than destroying them as a form of protest.

Although both COSAS and EE are grassroots organizations working for educational equity in South African townships, their methods of protest and communication with the government and the public vary tremendously. EE excels at building relationships both laterally, among learners from a diversity of schools and their communities, as well as vertically, with government officials who have decision-making power in the educational system. EE builds these relationships by presenting educational equity as a collective concern for all people in South Africa, rather than antagonizing those who might be recruited as allies. As the success of the 500 Windows Campaign will show, these constructive methods are useful in helping EE improve schools in Khayelitsha.

\section{The Beginning of the Campaign}

The first Equal Education youth group meeting was held on April 24, 2008 , with seven learners in attendance, a number that would soon grow as the campaign gained momentum (EE, 2008). EE staff members had been shadowing learners in Khayelitsha schools for three months prior, and they handed out flyers to advertise the meeting. As one of EE's first projects, staff members gave members of the youth group cameras to document anything at their schools that negatively impacted learning. One learner, Zukiswa Vuka, took a wrenching photograph of an entire bank of shattered windows at Luhlaza School. In fact, the damage extended beyond that one bank of windows - 500 windows at the school were broken and had been broken for at least five years (Shushwana \& Mzandisi, 2008). Learners and teachers had resigned themselves to the state of the windows, shivering through winter and attempting to cover the spaces with cardboard (Paton, 2009). The lack of windows not only made the school physically 
detrimental to learning, but the sense that the damage would never be fixed made it difficult for students to take pride in their school (EE, 2008). The broken windows were a serious problem at the school, and EE leaders felt that fixing them was an attainable goal for a first campaign and that an early success would help to build enthusiasm and a belief in the power of collective action among the learners. They also felt that fixing the broken windows at Luhlaza School would set a positive example for other schools dealing with similar problems (EE, 2008). Thus, EE chose its first campaign and set the goal of having the 500 broken windows at Luhlaza School fixed.

\section{First Steps: Petitions and Meetings}

Equal Education members began by appealing to the staff at Luhlaza School, holding meetings with teachers and the principal, Robin April, as well as administrators of the school management team. They also held meetings with the existing learner organization, the representative council of learners (RCL). The RCL reported that they had been asking the school management to address the issue for years, and the school management replied that they had written to the WCED, but nothing was being done (EE, 2008). EE members decided to create a petition that called for the windows to be fixed, but also committed learners to keeping them in good condition. The petition was signed by 2,000 community members, teachers, learners, parents and guardians, the Luhlaza School principal, professors, activists, and government officials such as Duncan Hindle (DirectorGeneral of Education), Mamphela Ramphele (former managing director of the World Bank, current trustee of the Rockefeller Foundation), Zackie Achmat, Judge Dennis Davis (Judge of the High Court of Cape Town), Professor Mary Metcalfe (who served on EE's board until she was appointed Director-General of Higher Education), and Noël Robb (an anti-apartheid activist through the women's organization the Black Sash). Although the campaign was focused on Luhlaza School, learners from other schools in Khayelitsha became involved out of concern for the collective state of schools in the township. For example, Mandisi Ngomba, a student at Trafalgar High, joined because he felt that the 500 Windows Campaign was the first step to addressing all of the problems in Khayelitsha schools (Community Media Trust, 2008).

EE presented the petition to officials from the WCED in a series of meetings. These meetings were led by Joey Hasson and Lwandiso Stofile, two of the organization's staff members, but weekly meetings for all EE members allowed them to share and discuss the outcomes of the WCED meetings and collectively determine the next steps (D. Isaacs, personal communication, December 5, 2009). During EE meetings, Equalisers also read the speeches and other writings of social activists from South Africa and elsewhere; moreover, they were able to solicit advice from EE's experienced activists who served on the 
board or worked for the organization (D. Isaacs, personal communication, December 17, 2009). First, EE members approached the circuit manager at the Metropole East District Office, Robin Botes, who claimed that the broken windows had never been brought to his attention before (EE, 2008). He referred them to an official at the WCED head office who was responsible for scheduled maintenance of Western Cape schools. This official also claimed he had never been told of the broken windows and that he had much more pressing concerns than broken windows (EE, 2008).

Equal Education decided to obtain an independent assessment of the cost of repairing the windows, and the best estimate was R17,000 (about \$2,200). The school would be able to contribute R5,000 and EE could match that amount with another R5,000, which meant R7,000 would still be needed (EE, 2008). At that point, several EE board members met with the Western Cape MEC for Education, Yousuf Gabru, and explained the outcomes of their previous meetings. Gabru was encouraging and supported learner involvement in educational change (EE, 2008). Gabru was experienced in the field of education and respected for his work; he had been, in fact, a teacher at Salt River High School during the time of the Soweto Uprising (Attwell, 2008), but he was new to the MEC position. Although he supported the window repair, he could not make the decision alone-he needed buy-in from other government officials to make it possible (D. Isaacs, personal communication, December 17, 2009). Thus, EE still needed to convince the officials directly responsible for Luhlaza School about the necessity of the repairs.

\section{Opposition and the Rally}

Equal Education had now been working on this issue for several months, and its members decided that they needed to attract greater public attention to the broken windows in order to motivate governmental action (EE, 2008). At this point, the organization's youth membership had grown to 150 members from ten different schools (EE, 2008). A rally to be held in front of the WCED office on Adderley Street in Cape Town was planned for October 10, 2008 (Shushwana \& Mzandisi, 2008). The youth leaders emphasized the importance of collaboration among schools, and learners across Khayelitsha told classmates, friends, and family about the rally. Several youth group members wrote articles in local newspapers and were interviewed on the radio. For example, Phatiswa Shushwana, a grade 8 learner at Luhlaza School, and Lwando Mzandisi, a grade 11 learner at KwaMfundo School, wrote an op-ed for The Cape Times describing the poor conditions in Khayelitsha schools, the purposes of EE, and the 500 Windows Campaign.

Although many WCED officials, including the MEC, were sympathetic to EE's goal, the officials who had opposed the campaign during the group's initial 
meetings with them grew more underhanded and severe in their opposition. One official interrogated Zukiswa Vuka, the student who took the pictures of the window, about EE's goals and her involvement with the organization (EE, 2008). Zukiswa wrote to the MEC to report this interrogation. The circuit manager, Robin Botes, told Lwando Mzandisi that "a black child from Khayelitsha was not capable of writing such an article" (EE, 2008, p. 14). Botes also held clandestine meetings with Khayelitsha school principals telling them not to participate in the rally and not to allow their students to participate (D. Isaacs, personal communication, December 5, 2009). According to Doron Isaacs, Botes had thus far been able to operate in a "mafia-like system of power" with impunity; he was not concerned about accountability for improving Khayelitsha's schools, but rather was focused on cementing his own position and was threatened by EE and the "impertinence" of children standing up for their rights (D. Isaacs, personal communication, December 5, 2009). Teachers were also discouraged from participating. Since their salaries and promotions were determined by the government, they were apprehensive to get involved with anything that might be challenging the existing system (D. Isaacs, personal communication, December 5, 2009). The South African Democratic Teachers' Union (SADTU) supported EE at the provincial level. However, at the local level, SADTU was influenced by Botes and other officials unsympathetic toward EE to oppose the rally. SADTU and another teachers' organization, the Khayelitsha Educators' Forum, sent letters to teachers telling them not to join the rally.

EE members continued to meet with unsympathetic officials to discuss the importance of fixing the windows. While some officials changed their minds, others remained focused on maintaining authority rather than improving the schools (D. Isaacs, personal communication, December 17, 2009). Despite the opposition, EE successfully recruited others to take part in the rally. Youth group meetings became a place to recharge and build cohesion among youth members. At the meetings, learners discussed campaign methods and objectives, particularly the importance of maintaining nonviolence and the methods of Nelson Mandela and other young protestors during the apartheid era (Shushwana \& Mzandisi, 2008). They also devised creative ways to convey their message to the WCED by writing poetry and songs about school conditions and creating posters and placards. Additionally, they collected more than 30 kilograms of broken glass from Luhlaza's playground, which they washed and used to make necklaces, bracelets, and other items to wear to the rally (EE, 2008).

EE staff members selected and trained marshals and spokespeople for the rally from among the youth group members (EE, 2008). On the day of the rally, 450 learners from 18 Khayelitsha schools, as well as learners from schools in other areas, Phillipi, Wallacedean, and the City Bowl, voiced their concerns about the broken windows at Luhlaza as well as the poor state of school facilities in all 
local schools (EE, 2008). Learners read speeches and poetry about the broken windows and carried placards with candid messages, such as "Freedom is no Freedom with Broken Windows" and "Concentration is Impossible without Windows" (EE, 2008). Unfortunately, a government official who spoke at the event dismissed the seriousness of the issue by claiming that Luhlaza School was the only Khayelitsha school with broken windows (it was not) and suggesting that the learners protesting had themselves broken the windows (EE, 2008). In fact, the windows had been broken for at least five years, so the problem had existed before many of these learners had entered the school. Despite this slight, the general public response and media accounts of the event were supportive of the campaign and appreciative of "responsible school children raising their concerns in a respectful and lively manner" (EE, 2008, p. 14).

\section{Follow-Up and Success}

After the rally, Equal Education members held a follow-up meeting with district officials at the WCED Metropole East office. The officials stated that the windows would be fixed, but did not provide a timeline. However, EE planned a public meeting about the broken windows for November 13, 2008, at Desmond Tutu Hall in Makhaza, Khayelitsha, and invited all community members, as well as education department officials (EE, 2008). Over 200 people attended the meeting, including MEC Gabru and a dozen other education officials. At the meeting, MEC Gabru announced that the WCED would provide R671,000 for repairs at the school, well above the R7,000 that EE had originally requested. Over the summer holidays in December 2008 and January 2009, every window at Luhlaza School was fixed. Lwandiso Stofile, EE's youth development officer for grades 10-12, called the outcome a great achievement for Khayelitsha's learners (Community Media Trust, 2008).

In evaluating the campaign, EE members determined several areas in which they sought to improve in the future. One area that EE's adult leaders identified was placing more decision-making power in the hands of the learners. Doron Isaacs noted that because this was the first campaign and the membership was still being established, EE staff made some of the decisions that ideally would have been collaborative; for example, staff members chose the marshals and speakers for the October $10^{\text {th }}$ rally from among the youth group members. In more recent campaigns, a youth group leadership committee consisting of peer-elected youth leaders from across schools in Khayelitsha makes the decisions regarding speakers at events and other relevant issues (D. Isaacs, personal communication, December 5, 2009). Another area in which EE plans to improve is in its engagement of teachers and parents (EE, 2008). Some teachers expressed support for the campaign privately, but were unwilling to pit themselves against unsupportive education department officials by offering public support. EE hopes 
to engage the teachers' union in constructive discussions about how to collaborate, as well as create parents' committees. Finally, although the goal of having the windows fixed has been accomplished, the rest of the promised R671,000 has yet to be disbursed to the school. EE has been writing to WCED to fulfill its commitment.

\section{A Case in Practice of Social Action}

The success of the 500 Windows Campaign is due to a number of characteristics vital to effective grassroots movements and social action. In terms of its structure, the campaign involved collective decision-making that can be described through four grassroots stages: initiation, legitimation, implementation, and evaluation (Willie, 2009). In the first stage, initiation, people in the community who have similar feelings about a problem come together to create a plan of action; in the legitimation stage, the group gains the approval of individuals respected in the community; in the implementation stage, the group has amassed the necessary resources to carry out the proposed action; and finally in the evaluation stage the group reflects on the strengths and weaknesses of their campaign and notes lessons learned and ways to improve their work in the future. Equal Education's efforts were also bolstered by its broad membership and support, its diversity, its critical mass of learners and community members from across schools in Khayelitsha, and its vertical linkages with experienced activists and influential members of society. Finally, in terms of its ethos, the idea of contributive and distributive justice (Willie et al., 2008) buoyed the learners' efforts in taking action to make a positive change for their schools. In this section I provide an analysis of the 500 Windows Campaign through the lens of social action (Willie, 1994).

\section{Structure of Campaign: Grassroots Stages}

In the initiation stage, the concerned individuals "establish internal organization ... identify common goals ... and propose appropriate action for the achievement of the goals" through group discussion (Willie, 1994, p. 57). In the 500 Windows Campaign, Zackie Achmat's concern about education in Khayelitsha, based on his prior work there, spurred the creation of Equal Education. However, the organization was not imposed on the community externally; rather, it was shaped by the already-existing concerns of learners and community members in Khayelitsha.

Choosing the broken windows as the initial campaign was effective for several reasons. First, it legitimized the first activity in which learners were asked to engage-photographing problems in their schools. If EE staff had asked 
learners to do this activity without any substantial follow-up, the activity would become meaningless. That is, learners would simply be documenting problems, but would not be given an avenue by which to address these problems. This lack of continuity might have caused learners to lose trust in the organization. Additionally, the broken windows were a concrete reminder of the inequities in Khayelitsha schools. As such, fixing the windows served as a tangible mark of achievement, instilling pride in EE members and their community and encouraging them to continue calling for not only better resources, but also solutions to more intractable problems, such as teacher retention and engagement. EE's priorities are shaped and led by learners, so it needed to establish that emphasis from the beginning by asking learners to share their concerns and then basing the first campaign on those concerns. Finally, the scope of the first campaign was also important. EE did not aim to fix broken windows in every school in Cape Town, or even every school in Khayelitsha with its first campaign, because such an effort would take significantly longer than fixing the windows at Luhlaza School. A first campaign often serves as a symbol of an organization's ability to make good on its promises, and in order to build cohesion among members and trust in the organization and its mission, the first campaign needs to be attainable within a relatively short period of time. EE's choice of the broken windows at Luhlaza School as its first campaign was effective and set a strong precedent for the organization's development because it was inclusive and learner-centered, and because it had attainable goals that sent a message to learners and the community-at-large that EE was a force to contend with.

The legitimation stage involves building support for the campaign. The meetings that EE members held with the staff of the school and existing support organizations were the first steps in this process. The creation of the petition was another vital step in the legitimation process. By presenting the petition to WCED officials and discussing their concerns in meetings with these officials, EE sought to legitimate the movement with those who would be directly responsible for fixing the windows. During the meetings with WCED officials, EE members engaged in principled negotiation by describing the negative impact that the broken windows were having on students' learning. According to Fisher and Ury (1983), principled negotiation is a way of making decisions based on common principles, rather than private interests, that is, "decid[ing] issues on their merits rather than through a haggling process" (p. 40). Because the 500 Windows Campaign was driven by students and focused on improving their education, it was based on principles that WCED was created to uphold. Thus, many WCED officials came to agree with EE that the broken windows needed to be repaired. Others like Robin Botes, the circuit manager, remained focused on their personal interest in protecting their own authority rather than the needs of the school and 
its learners. However, overall, the legitimation stage was successful in building support across a wide range of community members.

The implementation stage involves mobilization of personnel, organizational tools, and other resources to carry out the proposed plan of action. In the 500 Windows Campaign, the rally proved to be the major mobilizing event that allowed EE members to bring the broken windows to wide public attention and to demand action by the government. Students made use of media outlets to publicize the rally, through newspaper articles and radio interviews. The youth group meetings provided members with a place to pool their resources and create posters, art, and poetry that would be useful for the rally. Willie (1994) mentions that during the implementation stage, members might reach an impasse because of conflicting interests within the group. While EE members did not have any internal disagreements, they continued to face opposition from some government officials. During this time, EE members continued to engage in principled negotiation with opposing parties. The rally itself was successful because it brought together not only learners at Luhlaza School and learners that were members of EE, but it also drew support from learners outside of Khayelitsha. By holding follow-up meetings with WCED, EE ensured that the rally did not simply become an awareness event, but that it resulted in action on the part of the government.

After the windows were fixed, EE assessed its success and points for improvement in future work, the final stage of evaluation. Although the campaign was successful, EE engaged in an internal evaluation to determine what could have been done differently and what can be improved upon in the future, which they recorded in their annual report. As Willie et al. (2008) mention, evaluation is essential because without knowledge of what techniques have worked in the past, grassroots organizations often "reinvent the wheel" and victory or failure becomes a matter of chance, a little-understood phenomenon. Grassroots organizations, unlike bureaucratic organizations, often lack an administrative department dedicated to record-keeping, so valuable knowledge is often lost when a campaign is over (Willie et al., 2008). EE, however, is not only preserving knowledge of the campaign's successful techniques, but it has also identified specific areas for improvement and has taken steps to making these improvements in later campaigns.

\section{Leadership/Membership: Diversity, Critical Mass, and Vertical Linkages}

South Africa has often been called the "rainbow nation" because of its diversity, and Equal Education exemplifies that idea in terms of the ages, ethnicities, and educational experiences of its staff and members. As Willie et al. (2008) describe, diverse groups are able to devise plans of action that draw upon varied perspectives and ideas and "craft inclusive and comprehensive approaches 
to achieve their ... visions" (p. 190). EE's staff members have a variety of backgrounds and experiences that lend to the strength of the organization. For example, the staff members who attended schools in Khayelitsha have direct knowledge of the schools' issues, and the staff members who have organizing experience with other activist groups were able to bring that knowledge to EE. Additionally, staff members' work experience and further education in law, business, and other areas provided important specialized knowledge to support the learners' efforts.

The contributions of EE members also illustrate John Rawls' theory of native endowments as a common asset, an important foundation that has influenced Willie's (1994) work on theories of social action. Rawls' theory encompasses the idea that people should employ their talents and experience towards the good of others, as well as themselves, and that all members of society are connected and thus, individual talents are part of a greater whole (Rawls, 2001). By using their experience and advanced education to work towards the goal of improving primary and secondary schools in Khayelitsha, the staff members of EE are carrying out a Rawlsian idea of social justice. Most importantly, there was no single decision-maker; as political scientist Nelson Polsby (1963) comments, the most successful grassroots movements often have distributed leadership, in which "different leaders emerge in different issue-areas" (p. 124). In the 500 Windows Campaign, all EE members, whether staff or youth group members, were effectively leaders in different areas and distributed responsibility for a range of vital tasks, including communicating with government officials, building publicity, recruiting new members, and planning each step in the process. Willie (2008) points out that young people are the drivers of change in many grassroots campaigns, and this is certainly the case with EE.

In order to make the final, successful push for the repair of the broken windows, EE members needed to show that there was broad support for the initiative. In other words, the organization needed to gain a "critical mass" to impact the local government. Willie (1994) defines critical mass as a population of the size "necessary to have a noticeable impact on a social system" (p. 75). While the petition showed initial support for the 500 Windows Campaign, the rally was instrumental in gathering and exhibiting community-wide support. The youth group members took charge of publicizing the campaign in local media and in recruiting their friends, family, and community members. As a result of their hard work, a critical mass emerged that constituted a cross-section of the community, as well as supporters from other communities. The group was able to draw upon this broad base of support during the rally, and the "strength in numbers" around the broken windows issue was one of the important factors that influenced positive governmental action. 
Finally, EE succeeded in establishing "vertical linkages" with experienced and influential South African political figures, academics, and activists. According to Willie et al. (2008), vertical linkages are connections that the group has made with people who are outside of the group's membership and often hold leadership positions in the bureaucratic political structure or in other areas with political clout. EE's beginning as Zackie Achmat's idea certainly gave it the advantage of early connections with the prior generation of South African political activists. Achmat recruited other leaders for the organization's advisory board, such as then-professor Mary Metcalfe, who later became the DirectorGeneral of Higher Education in South Africa (after this campaign occurred). However, EE members were also successful in creating vertical linkages among local officials. For example, MEC Yousuf Gabru became a supporter after his meeting with the group. These linkages were not only valuable in terms of the credibility they lent to the campaign's goal but also for the resources, in terms of time and advice these leaders were able to offer.

\section{Ethos: Contributive and Distributive Justice}

The 500 Windows Campaign was rooted in the idea of contributive justice, the responsibility of the individual to the country and distributive justice, the responsibility of the country to the individual (Willie et al., 2008). As Willie et al. (2008) describe:

While the nation, as President Kennedy said, needs the support of its citizens, all citizens need and deserve help and support from their country. The individual and the community are interdependent; neither can go it alone. Individuals have the right to seek support from their towns, cities, provinces, and nation. And these collectives have the right to seek support from their participating members. (p. 7)

In campaigning for the windows at Luhlaza School to be fixed, EE members were calling upon the provincial government to fulfill its constitutional responsibility to provide quality education to its constituents. Their course of action involved presenting the situation to progressively higher levels of the bureaucratic structure (first the school level, then the local level, then the provincial level) and then assembling a critical mass of advocates when meetings were not spurring governmental action. While petitioning their government to improve educational conditions constituted a demand for distributive justice, the process also involved the practice of contributive justice because EE members were exercising their civic right and responsibility to present their concerns to the government. Notably, the petition created by EE members involved an outline of both contributive and distributive responsibilities. In terms of distributive 
responsibilities, it pointed out the government's obligation to provide and maintain school conditions that are conducive to learning; in terms of contributive responsibilities, it asked learners to commit to keeping the windows intact after they were fixed. By incorporating both contributive and distributive aspects to the issue, EE recognized the element of reciprocity (Becker, 1986) in the relationship between the government's and learners' responsibilities, that is, the idea of mutual contributions towards a shared purpose.

\section{Conclusion}

Equal Education's commitment to involving a wide range of community members in the common mission of repairing broken windows at Luhlaza School resulted in a clear victory for the campaign. Not only were the windows repaired, but additional funds were promised to the school. While the repaired windows certainly benefit learners, they also benefit other members of the school community, even those who were opposed to the campaign. Additionally, while some government officials chafed at the idea of being held accountable to their responsibilities of providing positive conditions for learning in Khayelitsha's schools, EE's appeal to their duties was beneficial to the expectations placed on education department officials. EE's campaign constituted a form of public accountability that is essential to the functioning of a democracy. When the concerns of a government's constituents are silenced, that government has reneged on its duty to uphold distributive justice. For Robin Botes and the unsupportive officials and teachers, EE's campaign served the important purpose of reminding them of their professional and civic duty to support the education of all students. Thus, the 500 Windows Campaign refocused decision-makers' attention on the most important issue for any educational system-students' learning.

The 500 Windows Campaign was part of a larger initiative, the Fix Our Schools Campaign, which focuses on improving the infrastructure of schools in Khayelitsha. The success of the 500 Windows Campaign has allowed EE to expand its focus to other issues in the schools. Later campaigns have concerned teacher absenteeism, the lack of teachers in certain core subjects like science, and the lack of libraries in many Khayelitsha schools. In addition to the campaigns that involve pressuring public officials to fulfill their responsibility, EE has run campaigns that call upon students to come to school ready to learn. The No Late Coming Campaign, for example, seeks to address learners' tardiness by appealing to the learners themselves (Equal Education, 2011). Again, the campaigns are focused on both a contributive and distributive sense of justice. Thus, the success of the 500 Windows Campaign served as a springboard for motivating $\mathrm{EE}$ members for future campaigns. 
The 500 Windows Campaign and EE's work in general has received international attention, garnering funding from The Atlantic Philanthropies and articles in The New York Times. Indeed, other grassroots organizations can learn a great deal from EE's techniques. For one, EE sets an excellent example in terms of building support among a variety of stakeholders. Though the students are the primary force behind the organization, its efforts to reach out to teachers, parents, community leaders, and government officials are instructive. Attempting to create dialogue before moving on to methods that officials might view as a threat is an essential act of due diligence. It also gives the organization a chance to build vertical linkages with officials who may become allies when the campaign progresses. For example, Yousef Gabru might not have come on board if EE had not initially tried to dialogue but instead started by holding a rally. Many organizations, including the contemporary COSAS, have skipped dialogue to direct protest, which has led the government to brand them as antagonistic. EE's attempts at engaging various decision-makers and stakeholders are effective and can serve as a model for building support among various constituencies. At the same time, EE itself noted in its annual report that this campaign did not engage parents and teachers to the extent that it hoped to. This weakness of the campaign is also instructive; not only did it encourage EE to begin parents' committees and to bring teachers into more of the early discussions in later campaigns, but it also called attention to the importance of building support among parents and teachers for any education campaign. Organizations that seek to empower youth must also include as partners the adults that have the most influence over youths' lives. As noted earlier, EE members study the work of anti-apartheid activists in order to inform their own work. Moreover, the organization makes use of the wisdom of past grassroots movements - not only do youth group members learn about antiapartheid activists, but they are able to solicit their advice directly. In making this connection, EE values the perspectives of both seasoned veterans and young people who are eyewitnesses to the current state of affairs; bridging the two groups builds an organization that is stronger through its diversity. In the same vein, EE engages in healthy self-reflection and monitors its progress, evaluative measures that many other grassroots organizations tend to overlook. In keeping track of its practices, EE is creating a repertoire of organizing knowledge that will be useful for its future campaigns as well as be informative and adaptable to those of other grassroots movements.

\section{Notes}

${ }^{1}$ Learner is the South African term for student.

2 I will henceforth refer to the case as the "500 Windows Campaign."

${ }^{3} \mathrm{R}$ is the abbreviation for rand, the South African currency. 


\section{References}

Attwell, P. (2008, August 4). Gabru appointed MEC for education in the Western. Retrieved http://wced.wcape.gov.za/comms/press/2008/602_Gabru.html

from

Barnett, R. V., \& Brennan, M. A. (2006). Integrating youth into community development: Implications for policy planning and program evaluation. Journal of Youth Development: Bridging Research and Practice, 1(2), 216. Retrieved March 1, 2011, from http://www.nae4ha.org/directory/jyd/jyd_article.aspx?id=bfae4d72-edae4d6f-b7ed-d5316d 66f6ef

Becker, L. (1986). Reciprocity. Chicago: University of Chicago Press.

Community Media Trust. (2008). Broken window campaign 2008. Retrieved from http://www.equaleducation.org.za/node/219

Constitution of the Republic of South Africa, 1996. chap. 2, sec. 29. Retrieved from http://www.info.gov.za/documents/constitution/index.htm

Delgado, M., \& Staples, L. (2008). Youth-led community organizing: Theory and action. New York: Oxford University Press.

Department of Education (2000). Education for all (EFA) 2000 assessment. Pretoria, South Africa: Department of Education. Retrieved from http://planipolis.iiep.unesco.org/upload/South\%20Africa/South_Africa_E FA_2000.pdf

Dugger, C. (2009, September 20). Eager students fall prey to apartheid's legacy. The New York Times. Retrieved from http://www.nytimes.com/2009/09/20/world/africa/20safrica.html?ref=afric a

Dwane, Y. (2009, November 13). EE understands COSAS anger but condemns their violence. Retrieved from http://www.equaleducation.org.za/eestatement-on-cosas-violence

Equal Education [EE]. (2008). Annual Report 2008. Retrieved from http://www.equaleducation.org.za/report_08

Equal Education. (2011). No Late Coming Campaign. Retrieved from http://www.equaleducation.org.za/latecomingcampaign_overview

Fedderke, J., de Kadt, R., \& Luiz, J. (2000). Uneducating South Africa: The failure to address the 1910-1993 legacy. International Review of Education, 46(3-4), 257-81.

Fedderke, J., \& Luiz, J. (2002). Production of educational output: Time-series evidence from socioeconomically heterogeneous populations - the case of South Africa, 1927-1993. Economic Development and Cultural Change, 51(1), 161-87. 
Fisher, R., \& Ury, W. (1983). Getting to yes: Negotiating agreement without giving in. New York: Penguin Books.

Fiske E., \& Ladd, H. (2004). Balancing public and private resources for basic education: School fees in post-apartheid South Africa. In L. Chisholm (Ed.), Education and social change in post-apartheid South Africa (pp. 57-88). Cape Town: Zed Books, HSRC Press.

Goodman, A., \& Goodman, D. (2008). Standing up to the madness: Ordinary heroes in extraordinary times. New York: Hyperion.

Hart, R. A. (1992). Children's participation: From tokenism to citizenship. Florence, Italy: International Child Development Centre, UNICEF.

Hart, R. A. (1997). Children's participation: The theory and practice of involving young citizens in community development and environmental care. New York: UNICEF/Earthscan.

Hosang, D. (2006). Beyond policy: Ideology, race, and the reimagining of youth. In S. Ginwright, P. Noguera, \& J. Cammarota (Eds.), Beyond resistance: Youth activism and community change (pp. 3-19). New York: Routledge.

Karon, T. (2001, April 19). South African AIDS activist Zackie Achmat. Time. Retrieved

from http://www.time.com/time/pow/article/0,8599,106995,00.html

Kirshner, B. (2009). "Power in numbers": Youth organizing as a context for exploring civic identity. Journal of Research on Adolescence, 19(3), 414440.

Lekiesa, K. S., Baker, B., \& Baldinic, J. (2009). Assessing participation in youth community action projects: Opportunities and barriers. Community Development, 40(4), 346-358.

O'Malley, P. (2005). The heart of hope. Nelson Mandela Centre of Memory and Dialogue. Retrieved from http://www.nelsonmandela.org/omalley/index.php/site/q/031v00000.htm

Paton, C. (2009, September 11). Windows to change. Financial Mail. Retrieved from http://secure.financialmail.co.za/09/0911/features/dfeat.htm

Polsby, N. (1963). Community power and political theory. New Haven, CT: Yale University Press.

Rawls, J. (2001). Justice as fairness: A restatement. Cambridge, MA: Harvard University Press.

Rechovsky, A. (2006). Financing schools in the new South Africa. Comparative Education Review, 50(1), 21-45.

Reddick, L. (1959). Crusader without violence: A biography of Martin Luther King Jr. New York: Harper.

Shushwana, P. \& Mzandisi, L. (2008, October 8). Pupils in drive to have school fixed so they can learn. Cape Times. 
South African History Online. (2000). Retrieved from http://www.sahistory.org.za/index.html

SouthAfrica.info. (2010). Retrieved from www.southafrica.info.

Integrated Regional Information Networks (IRIN). (2009, June 15). South Africa: Market forces part of xenophobic violence. Retrieved from http://www.unhcr.org/refworld/docid/4a3b589d23.html

Western Cape Education Department [WCED]. (2010). Retrieved from http://wced.wcape.gov.za/home/home.html

Willie, C. (1994). Theories of human social action. Dix Hills, NY: General Hall.

Willie, C. (2009). Community power, decision-making, and education. Lecture presented at the Harvard Graduate School of Education, Cambridge, MA.

Willie, C., Ridini, S., \& Willard, D. (2008). Grassroots social action. Lanham, MD: Rowman and Littlefield.

\section{Author}

Harini Angara is a development officer at The Posse Foundation, a college access and youth leadership development organization. She wrote the first draft of this paper as a graduate student studying with Dr. Charles Willie at the Harvard Graduate School of Education. 